\title{
Spatial and temporal variations of the subtidal meiobenthic community of the central coast of Venezuela
}

\section{Variación espacial y temporal de la comunidad meiobentónica submareal de la costa central de Venezuela}

\author{
Carlos Pereira $^{1 *}$, Evelyn Zoppi De Roa ${ }^{1 \dagger}$, Vanessa Hernández ${ }^{1}$, María Angélica Crespo ${ }^{2}$, \\ Joxmer Scott-Frías ${ }^{1}$ and Edie Montiel ${ }^{1}$
}

\begin{abstract}
Meiobenthos is a sediment-dwelling community with various taxonomic groups ranging in size from 63 to $500 \mu \mathrm{m}$. As a matter and energy link between primary producers and macrofauna, they have other functions in the ecosystem. Since this group has been scarcely studied in Venezuela, it was proposed to analyze the spatial and temporal variations in the composition and abundance of subtidal meiobenthos in the country's central coast. Samplings were conducted monthly from June 2014 to March 2015. In each sampling campaign, 12 random stations were established, and three samples were taken at each using a cylindrical sampler of $5.0 \mathrm{~cm}$ internal diameter. Organisms were identified and counted using microscopes, and data was processed using hypothesis tests (ANOSIM) and multivariate analyzes (SIMPER, nMDS). Meiobenthos showed a richness of 164 morphotypes and 14 phyla, with a dominance of planktonic copepods and foraminifers, followed by cnidarians and mollusks. Out of the total species reported, 84 are strictly benthic. Regarding abundance, there was a greater representation of foraminifera, followed by nematodes and mollusks, with values higher than those reported for tropical areas. Spatially, no differences were found in the composition and abundance of this community. However, two maximums were found throughout the study period, one starting in June until reaching maximum densities between August and October and the second one in February.
\end{abstract}

Keywords: Caribbean Sea, community structure, marine ecology, meiobenthos, meiofauna

1 Laboratorio de Ecología de Sistemas Acuáticos, Instituto de Zoología y Ecología Tropical, Universidad Central de Venezuela. Caracas, Venezuela. carlosjpereyra2@gmail.com* ORCID: http://orcid.org/0000-0002-5850-0775 ORCID: http://orcid.org/0000-0003-2659-0857 ORCID: http://orcid.org/0000-0001-9557-6333 ORCID: https://orcid. org/0000-0002-0901-6768

2 Escuela de Ciencias Aplicadas del Mar, Universidad de Oriente. Isla de Margarita, Venezuela. ORDIC: https://orcid. org/0000-0003-1336-0972 


\section{RESUMEN}

El meiobentos es una comunidad que habita en los sedimentos, tiene una variedad de grupos taxonómicos con tamaños entre 63 y $500 \mu \mathrm{m}$. Representan un vínculo de materia y energía entre los productores primarios y la macrofauna, con otras funciones para el ecosistema. En Venezuela, este grupo ha sido escasamente estudiado, por lo cual se planteó analizar las variaciones espaciales y temporales de la composición y abundancia del meiobentos submareal en la zona costera central del país. Los muestreos fueron realizados, por mes, desde junio de 2014 hasta marzo de 2015. En cada campaña de muestreo, se establecieron 12 estaciones aleatorias y, en cada una de ellas, se obtuvieron 3 muestras, con el uso de un dispositivo cilíndrico de $5 \mathrm{~cm}$ de diámetro interno. La identificación y conteo de los organismos se realizó con microscopio. Para el análisis de los resultados, se hicieron pruebas de hipótesis (ANOSIM) y análisis multivariados (SIMPER, nMDS). La meiofauna mostró una riqueza de 164 morfotipos y 14 phyla, con dominancia de copépodos planctónicos y foraminíferos, seguidos de cnidarios y moluscos. De estas especies, 84 eran estrictamente bentónicas. En cuanto a la abundancia, hubo mayor representación de foraminíferos, seguido de nemátodos y moluscos, con valores superiores a los reportados para áreas tropicales. Con respecto al espacio, no se encontraron diferencias en la composición y abundancia de esta comunidad. Sin embargo, temporalmente, se hallaron dos máximos, uno que inició en junio, que alcanzó las densidades máximas entre agosto y octubre, y el segundo en febrero.

Palabras claves: ecología marina, estructura comunitaria, mar Caribe, meiobentos, meiofauna

\section{INTRODUCTION}

In marine sediments, countless invertebrate species coexist and interact with each other, making up a complex trophic network (Giere, 2009). These organisms could be classified based on their size. In this work, we used the definition of meiobenthos from Coull \& Bell (1979) and Giere (2009) that groups aquatic intermediate-sized benthic organisms and includes taxonomically diverse metazoans and protozoa. In fact, those organisms that pass through a $500 \mu \mathrm{m}$ mesh-size sieve and are retained on a $63 \mu \mathrm{m}$ mesh, including permanent and temporary small metazoans and larger protozoans (ciliates, amoebozoans), are considered meiobenthos (Giere, 2009).
The meiobenthos community resides in interstitial spaces of sediments and above other organisms in all aquatic habitats, from the intertidal to the deep ocean areas in all latitudes (Wołowicz et al. 2011; Dupuy et al. 2015). Marine meiobenthos include more than 30 taxonomic groups, of which nematodes, foraminifera, harpacticoid copepods, cumaceans, ostracods, platyhelminthes, annelids, and juvenile stages of other groups are the most abundant (Giere, 2009; Wołowicz et al. 2011; Dupuy et al. 2015; Warwick, 2018).

Meiobenthos play a modulating role as a trophic link to the macrofauna. Secondary production in shallow aquatic systems is highly dependent on them because they transfer 
the energy produced by microalgae and bacteria to benthic consumers of higher trophic levels (Moncreiff \& Sullivan, 2001; Ansari et al. 2012). Meiobenthos modify the physical, chemical, and biological properties of sediments, participating in sediment stabilization, biogeochemical cycles, and waste removal (Wang et al. 2019). Additionally, it has been widely used for monitoring environmental quality due to its fast response to changes in the environment, species richness, and short life cycles with 3 to 5 generations per year (Giere, 2009; Ansari et al. 2012; Kitahashi et al. 2018).

In Venezuela, only a few studies have been conducted on this community. Woods \& Tietjen (1985) analyzed the meiobenthos of the Venezuelan basin; Reyes et al. (1999) studied the benthic community in the western side of the country; Martín et al. (2007) conducted a baseline study in the eastern part of the country; Vásquez-Suárez et al. (2010) analyzed meiofauna temporal variation in Raya Lagoon on Margarita Island; and Liñero et al. (2013) studied the spatial and temporal variation of the subtidal meiofauna on a beach in the eastern zone. For this reason, this study proposed to describe the spatial and seasonal variations of the composition and abundance of subtidal meiobenthos in the central coast of Venezuela.

\section{MATERIALS AND METHODS}

\section{Study area}

The study area is located in the north-central continental region of Venezuela, at the end of the foothills of Cordillera de la Costa. It includes the populations from Chirimena to Puerto Francés in the state of Miranda (Fig. 1). It is a heterogeneous area with deep and shallow coasts influenced by rivers and ephemeral streams, such as the Tuy river and the Tacarigua coastal lagoon (Herrera \& Bone, 2011). This area is characterized by a dry tropical climate, according to Köppen's climate classification, with an average temperature around $29.1^{\circ} \mathrm{C}$. Annual precipitation is $1,327 \mathrm{~mm}$ with the highest precipitation in November (Schwarz, 2014). During the first months of the year, coastal upwelling occurs, which keeps the waters fertilized during the dry season (Castellanos et al. 2002). Regarding marine currents, the area presents a current pattern with an EastWest direction (Pereira et al. 2020).

\section{Sampling design}

Samples were taken in each zone from a multistage cluster design with subsamples. A $12 \mathrm{~km}$ coastline was established and divided into three zones separated by areas with sandy bottoms of $500 \mathrm{~m}$ approximately. For purposes of this study, these sandy areas were considered barriers between zones. 


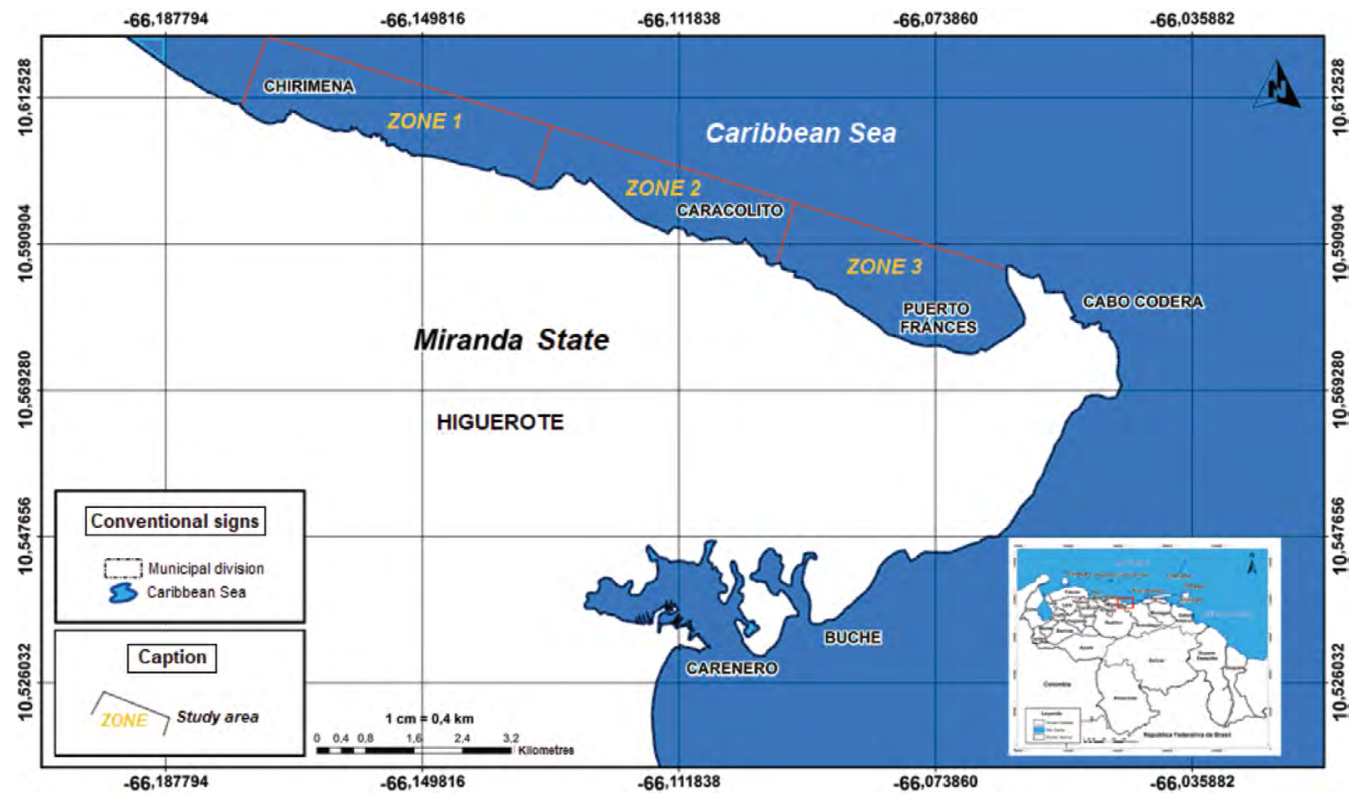

Fig. 1. Location of the sampling zones in the coastal area between Chirimena and Puerto Francés, Venezuela

Fig. 1. Ubicación de las zonas de muestreo en el área costera entre Chirimena y Puerto Francés, Venezuela

Zones were called Chirimena $\left(10^{\circ} 36^{\prime}\right.$ 42 " N, 66 $60^{\circ}$ ' $37.15^{\prime \prime} \mathrm{W}-10^{\circ} 36^{\prime} 1.3$ " $\left.\mathrm{N} 66^{\circ} 8^{\prime} 8.3^{\prime \prime} \mathrm{W}\right)$, Caracolito $\left(10^{\circ} 36^{\prime}\right.$ $1.3 " \mathrm{~N} \mathrm{66^{ \circ } 8}$ ' 8.3" W - 10॰35'30.7" $\left.\mathrm{N} 66^{\circ} 66^{\prime} 6.7^{\prime \prime} \mathrm{W}\right)$, and Puerto Francés $\left(10^{\circ} 35^{\prime} 30.7^{\prime \prime} \mathrm{N} 66^{\circ} 6{ }^{\prime} 6.7^{\prime \prime} \mathrm{W}-10^{\circ} 34^{\prime}\right.$ 52 "N 66³' 40.8” W) (Fig. 1).

Sampling campaigns were conducted monthly from June 2014 to March 2015 at the three zones mentioned above (Chirimena, Caracolito, and Puerto Francés). In each sampling zone, four stations were randomly selected every month, resulting in a total of 12 stations per month (Fig. 1). Two criteria were established for the randomization of the sampling stations.
The first one was creating a grid on a map with five rows and five columns in each sampling zone. Each cell had a dimension of 50 meters long towards the sea and 870 meters along the coast with depths from 5 to $25 \mathrm{~m}$. The second one refers to the bottom type, viz. sand and rock. Each cell was assigned a number, and sampling sites were chosen monthly through a random number selection system.

\section{Sampling}

Sediment samples were collected at each station by SCUBA divers, using a $0.25 \mathrm{~m}^{2}$ quadrant divided into 25 quadrants of the same size. Three (3) random samples were taken inside the 
quadrant, using a cylindrical corer of 5 $\mathrm{cm}$ inner diameter slowly buried about $1 \mathrm{~cm}$ in sandy substrates. The sampler was then covered to obtain a layer of sediment with the inhabiting organisms using suction. In the case of rocky substrates, the sediment surface was scraped with the same sampler with circular movements at the rock bottom. The sampler was quickly covered on both sides. On the boat, samples were fixed with a $5 \% \mathrm{v} / \mathrm{v}$ solution of buffered formalin.

\section{Laboratory analysis of samples}

Sediment samples were washed with distilled water through a set of 500 and $63 \mu \mathrm{m}$ sieves. The filtered material was washed eight times inside the $63 \mu \mathrm{m}$ mesh sieve and stained with Rose Bengal. Organisms were identified and counted directly, observing the sediment under a Leica MZ95 microscope with a 400X magnification in the Ecology of Aquatic Systems laboratory at the Central University of Venezuela. The works of Willey (1930, 1932, 1935), Day (1967), Owre \& Foyo (1967), Trégouboff \& Rose (1967a;b), Wells (1978, 1979), Platt \& Warwick (1983; 1998), Fiers (1984, 1986a, b, 1995), Todd \& Laverack (1991), Suárez-Morales \& Gasca (1997), Warwick et al. (1998), Conway (2012a,b), and Johnson \& Allen (2012), as well as the Nemys database (Bezerra et al. 2020) were used as references to identify samples. Organisms were identified to the lowest possible taxonomic level, some to species and others to family, genera, or morphotype. The validity of the scientific names was verified at marinespecies.org (WoRMS, 2020).

\section{Statistical analysis}

Monthly data on the number of species or morphotypes, density, and Shannon-Wiener biological diversity of the meiobenthic community at three zones at the Caribbean Sea is presented, using descriptive statistical techniques. As part of the community's characterization, hypothesis tests were performed from a bifactorial model (month and zone) without interactions, using a similarity analysis (ANOSIM). In cases where significant differences were found with a type I error $(\alpha)=0.05$, subsequent tests (Less Significant Differences, LSD) were applied. A SIMPER test based on abundance was performed to determine the percentage of similarity between sample groups according to the time and space factors. Non-metric multidimensional scaling (nMDS) ordering analyzes were applied to visualize the pattern of similarity of the samples (Clarke et al. 2014). The Bray-Curtis similarity index was used for both analyzes. Statistical analyzes were performed with the PAST 4.03 software (Hammer et al. 2001).

\section{RESULTS}

\section{Total community composition}

Meiobenthos of the marine and coastal zone between Chirimena and 
Puerto Francés was represented by 164 species or morphotypes and 14 phyla. The phylum with the highest number of species was Arthropoda with 69 morphotypes represented by 48 species of copepods (representing 29.3\% of the total richness), 8 decapods, 3 cladocerans, 3 amphipods, 2 isopods, 2 cirripeds, 1 stomatopod, 1 ostracod, and 1 mysid. Other important groups were Foraminifera with 34 species $(20.7 \%)$, Cnidaria with $16(9.8 \%)$, Mollusca with 13 (7.9\%), Chordata with 9 (5.5\%), and Polychaeta with $6(3.7 \%)$. Moreover, other taxonomic groups with less than 5 species were identified, belonging to the phyla Bryozoa, Chaetognata, Ciliophora, Echinodermata, Nematoda, Phoronida, and Radiozoa, which together represented $11 \%$ of the total species. Only
84 species of the total reported are considered strictly benthic (51\%). The rest of the species belonged to plankton and were found in the sediment samples at very low densities (Fig. 2).

Total densities of meiobenthos varied between 1,230 and 23,058 ind $/ 10 \mathrm{~cm}^{2}$ with an average density of $8,900 \pm 4,037 \mathrm{ind} / 10 \mathrm{~cm}^{2}$. Regarding the density by taxonomic groups, a greater contribution of foraminiferans was observed with an average density of $6,729 \pm 3,187 \mathrm{ind} / 10 \mathrm{~cm}^{2}$ that represented approximately $76.2 \%$ of the total community. It was followed by nematodes with $967 \pm 609 \mathrm{ind} / 10$ $\mathrm{cm}^{2}(11 \%)$, mollusks with $739 \pm 551$ ind $/ 10 \mathrm{~cm}^{2}(8.4 \%)$, and copepods, mainly harpacticoid, with $346 \pm 379$ ind $/ 10 \mathrm{~cm}^{2}(3.9 \%)$. The most abundant species were Neogloboquadrina

sp., Globorotalia me-

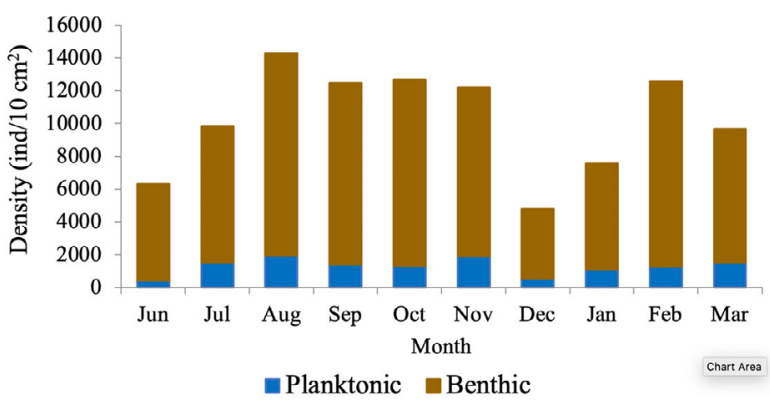

Fig. 2. Monthly variation of the mean density of meiobenthos in the coastal zone between Chirimena and Puerto Francés, June 2014 - March 2015, showing the proportion of planktonic and benthic species

Fig. 2. Variación mensual de la densidad media del meiobentos de la zona costera entre Chirimena y Puerto Francés entre junio 2014 y marzo 2015, mostrando la proporción de las especies planctónicas y bentónicas nardii, Globorotalia scitula, Quinqueloculina sp., Woodringina sp., and Globigerina sp. foraminiferans, Euchromadora vulgaris and Epsilonema sp. nematodes, the pteropod Limacina helicina, an unidentified gastropod, and several genera and species of harpacticoid copepods such as Euterpina acutifrons, Harpacticus 
spp., Longipedia sp., Microsetella rosea, Paralaophonte sp., Peltidium sp., Phyllopodopsyllus sp., Pseudobradya sp., and Tisbe spp.

\section{Spatial variability}

No remarkable differences were observed in the spatial richness of the three established zones (ANOSIM: $\mathrm{R}=0.146 ; P=0.07)$. Richness was between 121 and 124 with the same proportion of taxonomic groups. Regarding the substrate type, greater richness was found in the sandy substrate with 146 species compared to the rocky substrate with only 133 species. Although the proportion of taxonomic groups was similar, the sandy substrate had particular species, including some planktonic species not found in the rocky substrate. Strictly considering the meiobenthic species, the following species were found in the sandy substrate: Foraminifera $\mathrm{Am}$ monia sp., Baculogypsina sphaerulata, and two species of the order Rotaliida, the harpacticoid copepods Ameira trisetosa and Laophonte sp., an amphipod of the genus Elaspomus sp., three mollusks, two polychaetes, and an unidentified Phoronidae. The following species were found in the rocky substrate: the tintinnid Undella hyalina and the copepods: Tisbe spp. and Robertsonia sp.

Using a two-way nested ANOSIM test to evaluate species composition (in which zones were included within months), no significant difference was found between zones $(\mathrm{R}=0.133 ; P=0.1)$. An average density of $8,341 \pm 3,087 \mathrm{ind} / 10 \mathrm{~cm}^{2}$ was obtained in zone 1 (Chirimena), $9,029 \pm 3,968 \mathrm{ind} / 10 \mathrm{~cm}^{2}$ in zone 2 (Caracolito), and 8,993 $\pm 3,965$ ind $/ 10$ $\mathrm{cm}^{2}$ in zone 3 (Puerto Francés). The proportion of taxonomic groups was similar between zones, where nematodes and mollusks were the ones generating these slight differences. The SIMPER test showed an average similarity among the samples of $27.71 \%$ in zone $1,28.34 \%$ in zone 2 , and $23.47 \%$ in zone 3 . The species contributing over $70 \%$ to this similarity were the foraminiferans Globorotalia menardii, Globorotalia scitula, and Neogloboquadrina sp., and the nematode Euchromadora vulgaris.

Additionally, a one-way ANOSIM test was performed to compare the species composition between the two types of substrates, and no significant differences were found (ANOSIM, $\mathrm{R}=0.033$; $P=0.3$ ). This result was confirmed with the nMDS, which showed a single point cloud (Fig. 3). Using the SIMPER test, a $30.79 \%$ similarity was obtained among sandy substrate samples, $22.34 \%$ among rocky substrate samples, and $25.5 \%$ between both substrates. The foraminiferans Globigerina sp2., Globorotalia menardii, Globorotalia scitula, Neogloboquadrina sp., and Woodringina spp., one gastropod, the nematode Euchromadora vulgaris, and several Calanoid copepods contributed with more than $70 \%$ 


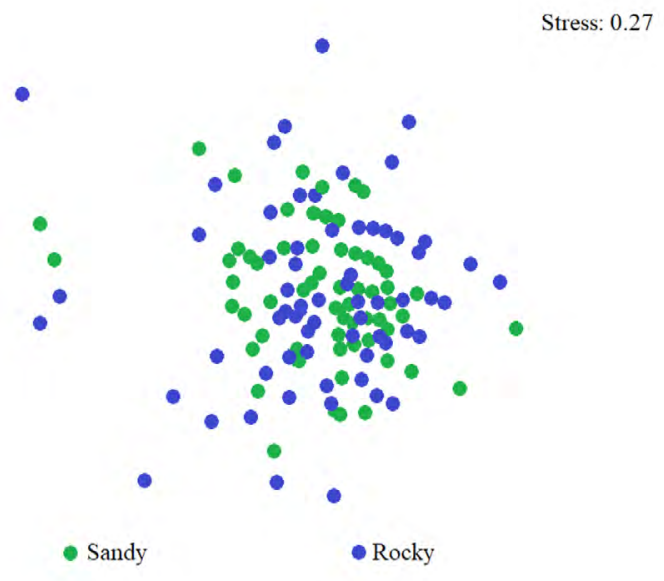

Fig. 3. Non-metric multidimensional scaling analysis (nMDS) of the total abundance of meiobenthos in sandy substrate (green) and rocky substrate (blue) in the coastal zone between Chirimena and Puerto Francés, June 2014 - March 2015

Fig. 3. Análisis de ordenación de escalamiento multidimensional no métrico (nMDS) de la abundancia total del meiobentos en sustrato arenoso (verde) y rocoso (azul) de la zona costera entre Chirimena y Puerto Francés entre junio 2014 y marzo 2015

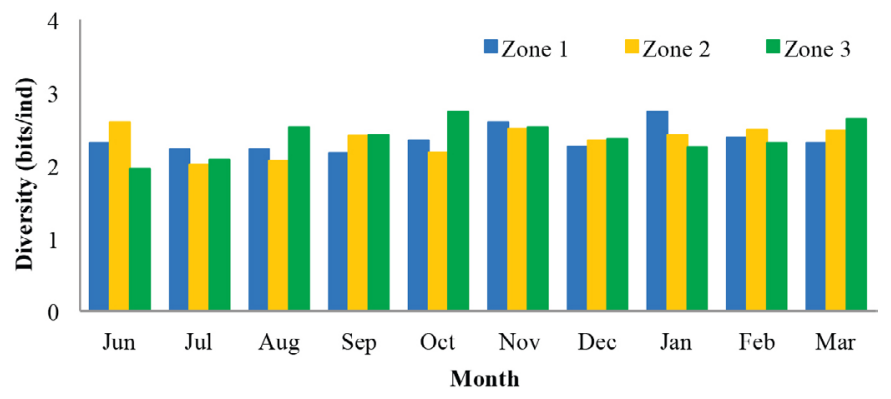

Fig. 4. Shannon biological diversity index of meiobenthos by zone in the coastal zone between Chirimena and Puerto Francés, June 2014 - March 2015. Zone 1 (blue): Chirimena, Zone 2 (yellow): Caracolito, and Zone 3 (green): Puerto Francés.

Fig. 4. Índice de diversidad biológica de Shannon del meiobentos por zonas en la zona costera entre Chirimena y Puerto Francés entre junio 2014 y marzo 2015. Zona 1 (azul): Chirimena, zona 2 (amarillo): Caracolito y zona 3 (verde): Puerto Francés to these similarities. Regarding the biological diversity index, the lowest diversity values were estimated in zone 1 with an average of 2.5 bits/ind, while zones 2 and 3 had both a mean value of 2.6 bits/ind (Fig. 4).

\section{Temporal \\ variability}

Regarding the total temporal variability of richness, two maximums were observed: one in June, in which 86 species were identified, and the other in November with 92 identified species. These peaks coincided with the transitions between the rainy (August-November) and dry (January-March) seasons. Samples presented a similar proportion of species with some exceptions. For example, the copepods proportion varied from 27 to $30 \%$, except in February, when it decreased to $22 \%$ 
with 17-24 species. Foraminifera presented percentages between 20 and $22 \%$, except in October, February, and March when their proportion increased, varying between 27 and 32\%. Foraminifera richness varied between 14 species in July, August, and September and 25 species in October. Another group that showed varied proportions between months was Cnidaria, going from 0 species in August to 8 species in June and November, influencing the temporal variation of total richness. The rest of the groups remained somewhat constant (Fig. 5).

Regarding temporal variability of density, two maximum densities were observed, the first between August and November (rainy season) with an average density of 10,825 $\pm 2,898 \mathrm{ind} / 10 \mathrm{~cm}^{2}$ and the other in

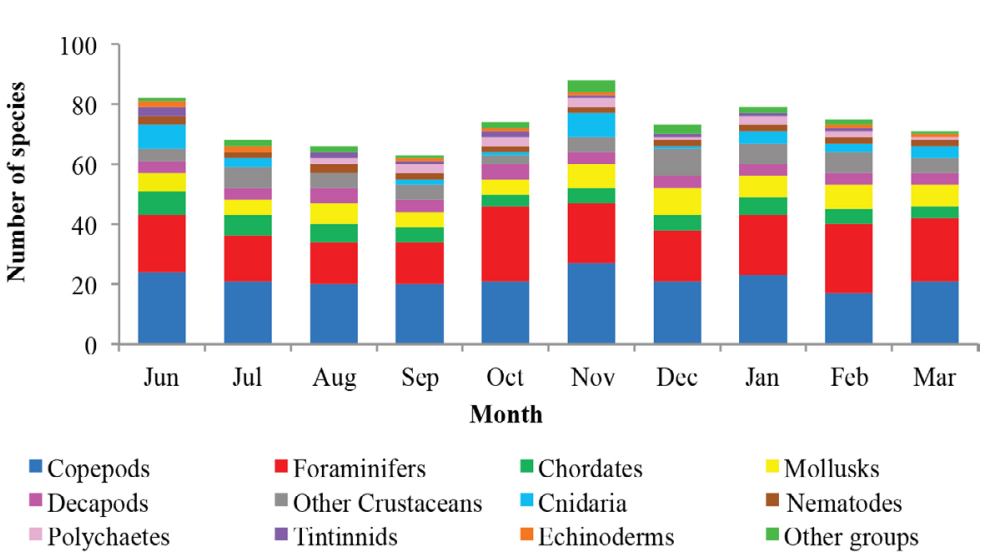

Fig. 5. Monthly variation of the richness of meiobenthos in the coastal zone between Chirimena and Puerto Francés, June 2014 - March 2015

Fig. 5. Variación mensual de la riqueza del meiobentos de la zona costera entre Chirimena y Puerto Francés entre junio 2014 y marzo 2015
February with $10,478 \pm 4,832$ ind $/ 10$ $\mathrm{cm}^{2}$. The lowest density was obtained in December with 3,991 $\pm 1,555 \mathrm{ind} / 10$ $\mathrm{cm}^{2}$ (Fig. 6). The two-way nested ANOSIM test showed significant differences between months $(\mathrm{R}=0.587$; $P=0)$. The post-test to compare each month indicated differences between July/November, July/January, July/ February, July/March, August with the months between November and March, September/December, September/January, September/March, October/November，October/January, as well as between December, January, February, and March.

As far as the SIMPER test, samples within each month presented different composition similarities with an undefined pattern. The highest similarity values $(>35 \%)$ occurred in July, September, and October, and the lowest was in June $(12 \%)$. Regarding the similarity between months, it was found that June presented a similarity with the rest of the months ranging from 9 to $12.1 \%$, July $12.1-29.8 \%$, August $9.7-26 \%$, September 10.7 


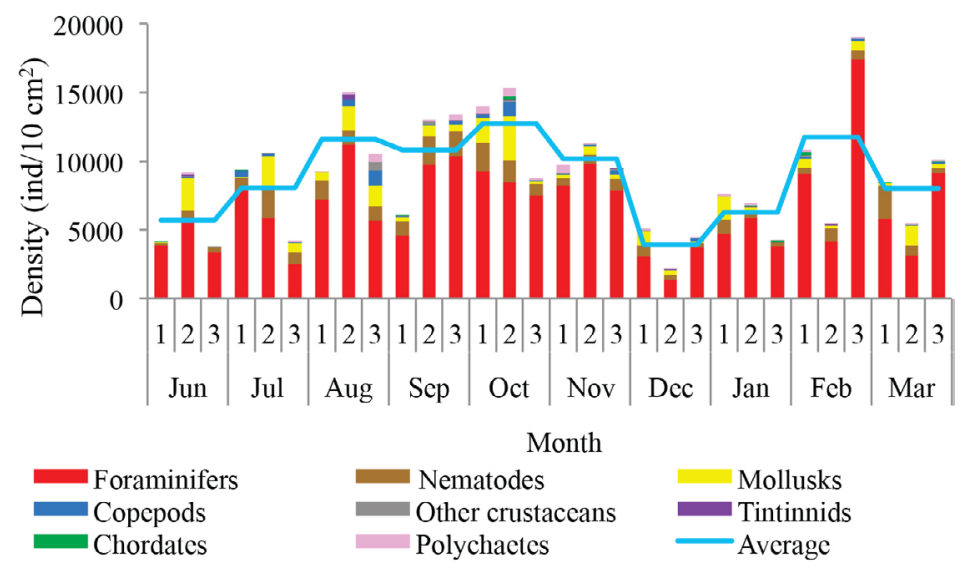

Fig. 6. Spatial and temporal variation of the mean density of meiobenthos in the coastal zone between Chirimena and Puerto Francés, June 2014 - March 2015

Fig. 6. Variación temporal y espacial de la densidad media del meiobentos de la zona costera entre Chirimena y Puerto Francés entre junio 2014 y marzo 2015

- 27.5\%, October 9.7 - 21.6\%, November 11.5 - 27.5\%, December 9.6 - 23.6\%, January 9 - 24.5\%, February 10.9 - 29.8\%, and March 9.3 - 24.9\%. Some foraminifera, nematodes, and mollusks species contributed in a greater proportion to this similarity.

The Shannon Diversity Index showed temporal variation with values between 1.8 (low diversity) and 3.1 bits/ind (high diversity). Two diversity peaks were observed, the first one in October with 2.9 bits/ind and the second one between February and March with 2.7 bits/ind. The lowest mean diversity value was 2.2 bits/ind in June and December (Fig. 4).

\section{DISCUSSION}

In this study, a diverse meiobenthic community with a significant number of copepod species characteristic of the zooplankton community was observed in the central coast of Venezuela, from the Chiminera region to Puerto Francés. Although their densities were low, their presence in the meiobenthos could indicate the link between the planktonic and benthic communities, where these planktonic organisms migrate to the bottom to feed on benthic organisms (Schnack-Schiel \& Isla, 2005). As in this study, Liñero et al. (2013) identified 14 taxa on a beach in eastern Venezuela. The authors excluded foraminifera from their analysis, and found a dominance of nematodes with an average density of $155.80 \pm 29.07 \mathrm{ind} / 10 \mathrm{~cm}^{2}$ that represented $58.36 \%$, followed by ostracods with $45.60 \mathrm{ind} / 10 \mathrm{~cm}^{2}(17.10 \%)$, and harpacticoid copepods with 41.96 ind $/ 10 \mathrm{~cm}^{2}(15.7 \%)$.

Liñero et al. (2013) explained the difficulty of making comparisons with other studies due to the methodological differences that exist during 
sampling, data analysis, and interpretation of results. However, they compared their results with other studies worldwide, finding a low density for this zone. In fact, by excluding foraminifera quantified in this study, we obtained a meiobenthic density three times higher than the one obtained by Liñero et al. (2013) on San Luis beach. However, the richness of foraminifera was similar to that found in Cartagena bay, Colombia (Osorio-Dualiby \& Álvarez-León, 2011).

The density values estimated in this study were eight times above those reported by Soltwedel (2000) for tropical areas, which, according to Coull (1999), are in the order of 1,000 ind $/ 10 \mathrm{~cm}^{2}$ in soft marine sediments. This is evidenced when comparing the densities obtained in depths of the Venezuelan territorial sea, in which the density of meiobenthos was between $13-153 \mathrm{ind} / 10 \mathrm{~cm}^{2}$ (Woods \& Tietjen, 1985), the central zone of the Great Barrier Reef in Australia (26 m deep) with 220-1,010 ind/10 $\mathrm{cm}^{2}$ (Hansen et al. 1987), southeastern Costa Rica (5 m deep) with $99-575 \mathrm{ind} / 10 \mathrm{~cm}^{2}$ (Guzmán et al. 1987), Rocks Atoll in northeast Brazil (2.5 m deep) with $278-4,165 \mathrm{ind} / 10 \mathrm{~cm}^{2}$ (Netto et al. 2003), Bay Lagoon in Jamaica $(<10$ $\mathrm{m}$ deep) with $327.7-5,518.9$ ind $/ 10$ $\mathrm{cm}^{2}$ (Edwards, 2009), Cienfuegos Bay in Cuba (9 m deep) with 780.02 $\pm 772 \mathrm{ind} / 10 \mathrm{~cm}^{2}$ (Armenteros et al. 2009), intertidal zones in Suriname and French Guiana ( $<1 \mathrm{~m}$ deep) with $1,760-4,400 \mathrm{ind} / 10 \mathrm{~cm}^{2}$ (Dupuy et al. 2015), and tropical beaches in Brazil $(<6$ m deep) with $288-2,553$ ind $/ 10$ $\mathrm{cm}^{2}$ (Baia \& Venekey, 2019). These differences could be the result of different depths, temperatures, and other environmental conditions.

In most studies, the dominant group is nematodes (Giere, 2009; Baia \& Venekey, 2019). However, foraminifera were the dominant group in this study. This was also the case in Cienaga Los Olivitos, on the Venezuelan west coast, with an average density of $3.82 \mathrm{ind} / 10 \mathrm{~cm}^{2}$ and a foraminifera dominance of $77.09 \%$ (Reyes et al. 1999); Boca Serpent, the strait between southern Trinidad and the Orinoco Delta, with an average density of $305.7 \pm 345.1 \mathrm{ind} / 10 \mathrm{~cm}^{2}$ and a foraminifera representation of $85 \%$ of the community; the Gulf of Paria with an average density of $120.3 \pm 142.4 \mathrm{ind} / 10$ $\mathrm{cm}^{2}$ and a representation of $50 \%$ foraminifera and $50 \%$ polychaetes; Deltana platform with a foraminifera dominance of almost $100 \%$ at a $60 \mathrm{~m}$ depth and average densities between 7,683 \pm $6,345 \mathrm{ind} / 10 \mathrm{~cm}^{2}$ and $43,360 \pm 38,591$ ind $/ 10 \mathrm{~cm}^{2}$ (Martín et al. 2007); a beach with coral reefs on Caño Island, on the Pacific coast of Costa Rica, with densities between 99 and 575 ind $/ 10$ $\mathrm{cm}^{2}$ (Guzmán et al. 1987); and an area away from coral reefs in the Xpicob inlet in the coastal area of Campeche, Mexico (Avilés-Ramírez et al. 2016). 
Páez et al. (2001) indicated that foraminifera represent the most abundant group of organisms in the marine meiofauna with more than 5,000 species, of which benthic species are 30 times more numerous than the planktonic species. These protists inhabit all depths of the seas, demonstrating a high level of efficiency and ecological adaptability to different substrates (Páez et al. 2001, Sabbatini et al. 2014), which explains the high dominance of foraminifera in this study.

Other important groups in this study were nematodes with $11 \%$ of total abundance and mollusks with an $8.4 \%$ representation. Gourbault et al. (1998) pointed out that nematodes are the most dominant group in reef areas, which suggests their need to stay in more stable or protected areas. In fact, Dye \& Lasiak (1986) and Liñero et al. (2013) found that nematodes had preferences for fine sands. Although the sediments were not characterized in this study, this area is characterized by being of high energy with muddy-sandy sediments (Solé \& Vera, 1997, Pereira et al. 2020), which explains the abundance values found in this research.

Despite not being the most representative group, the density of nematodes in this research exceeded the one obtained by Ansari et al. (2012) in a coastal area in southeast India with densities between 34.6 and 207.7 ind $/ 10 \mathrm{~cm}^{2}$, representing $57 \%$ of the total abundance. These researchers reported copepods with a density between 11.57 and $54 \mathrm{ind} / 10 \mathrm{~cm}^{2}$, which represented about $15 \%$ of total abundance, and foraminifera with densities between 16 and $47.29 \mathrm{ind} / 10 \mathrm{~cm}^{2}$, representing $14 \%$ of the abundance. However, unlike their study (Ansari et al. 2012), ours did find mollusks.

The nematode density estimated in this study $\left(1,218 \pm 628 \mathrm{ind} / 10 \mathrm{~cm}^{2}\right)$ coincided with the one estimated by Vásquez-Suárez et al. (2010) in Raya lagoon $\left(1,209 \mathrm{ind} / 10 \mathrm{~cm}^{2}\right)$ and by Díaz-Asencio et al. (2009) in Cien Fuegos bay, Cuba $(1,212.5 \pm 889.7$ ind/ $10 \mathrm{~cm}^{2}$ ). Moreover, the nematode species identified in this study coincided with the most frequent and abundant in the Cuban archipelago, such as Euchromadora vulgaris and Epsilonema sp. (Pérez-García et al. 2020). Another important group in terms of abundance was harpacticoid copepods.

A study conducted by Alfonso \& López (2006) in several coastal localities in the northern zone of Havana showed wide-ranging densities between 892.12 and 7,133.48 ind $/ 10$ $\mathrm{cm}^{2}$, excluding foraminifera, of which nematodes represented $49-90 \%$ of total abundance, while copepods represented 51-66\%, which are at least an order of magnitude higher than the abundances obtained in this study. Soltwedel (2000) saw that in the majority of oceanic areas, the proportion of nematodes exceeds $75 \%$ of the total 
meiobenthos, excluding foraminifera. Only in the tropical areas (in western India and northeast Australia), did nematodes constitute less than $60 \%$ of the total abundance of microscopic metazoan organisms (Soltwedel 2000). In fact, an analysis of 621 stations worldwide showed an average nematode density of $525.27 \mathrm{ind} / 10$ $\mathrm{cm}^{2}$ and $1,116.25 \mathrm{ind} / 10 \mathrm{~cm}^{2}$ in 107 samples at depths between 20 and 200 $\mathrm{m}$ (Mokievskii et al. 2007). The results obtained in this work are in the interval reported by these authors.

Although granulometry was not analyzed in this study, samples were collected in a heterogeneous area with rocky and sandy substrates, consisting mainly of medium to coarsegrained sand. As indicated by Decho et al. (1985), Armenteros et al. (2009), Vásquez-Suárez et al. (2010), and Liñero et al. (2013) in their spatial analyzes, the lowest meiobenthic densities were obtained on sandy beaches, while the highest were found in finer grain sediments. In contrast, Ruiz-Abierno \& Armenteros (2016) found no differences in the distribution of meiobenthos depending on the substrate, inferring that hydrodynamics nullified these differences as found in this study. Temporal patterns with two increases in density (August-November and February-March) during this study period coincided with the one obtained by Liñero et al. (2013). However, a gap was evident in which the highest densities were reached from October to December and the lowest in February, July, and August (Liñero et al., 2013).

Although no correlations were made in this study with environmental variables, some studies indicate a trend to increase density during the dry season (Coull, 1970; Chindah \& Braide, 2001). In the coastal area between Chirimena and Puerto Francés, an increase was observed in density during the rainy season and maximum temperatures, coinciding with what was found by Venekey et al. (2014) in an intertidal zone in Brazil, Zaleha et al. (2016) on Karah Island in China, and Baia \& Venekey (2019) on sandy beaches in Brazil. This could be explained by the availability of food during the rainy season due to the enrichment of the marine environment by the discharge of nutrients from the adjacent rivers and streams.

Other variables that influence the composition and distribution of meiobenthos are salinity, water movement, sediment characteristics, food quality and availability, predation, dispersal, biogenic structures, and biological disturbance (Edwards 2009; Giere, 2009; Baia \& Venekey, 2019). However, Alfonso \& López (2006) found that changes in the structure and composition of the meiofaunal communities were related to stochastic events such as storm drains, tropical storms, and hurricanes. 
In addition, a study conducted by Kumary (2016) about the temporal variation of the interstitial meiofauna in India indicated that some factors such as ecological interactions between species, organic matter content, sediment grain size, and oxygen had a considerable influence on the spatial variation of the components of the meiobenthic community. While temporarily, taxonomic composition, density, and distribution depend on increases in temperature and salinity, the stability of sediments, and probably the availability of food favored by pre and post-monsoon population enrichment. Therefore, subsequent studies should estimate other variables related to the characteristics of the sediment and complement community studies with population analysis of the modulating species of this community.

\section{CONCLUSIONS}

These results represent a contribution to the knowledge on meiobenthos ecology in Venezuela and the Caribbean Sea. Meiobenthos showed high richness with the presence of planktonic species and an outstanding representation of copepods and foraminifera, followed by cnidarians and mollusks. Temporally, two maximums in species richness were observed, while spatially, no differences were observed between the three established zones, although samples from the sandy substrate presented a greater number of species than the rocky substrate. Concerning abundance, there was an important representation of foraminifera, followed by nematodes and mollusks. Temporarily, two peaks were found. The first one began in June with progressive increases until reaching maximum densities between August and October. Subsequently, density gradually decreased from October to December, after which it started to climb until reaching the second maximum in February.

\section{ACKNOWLEDGMENTS}

We would like to thank Petróleos de Venezuela, S.A. for funding the project and the reviewers for their contributions to improve the quality of the manuscript.

\section{BIBLIOGRAPHY}

Alfonso, H. \& López, C. (2006). Distribución espacio-temporal de la meiofauna béntica en cuatro playas del Litoral Norte de la Habana. Rev. Biol. Trop., 54(3), 985-995. https://doi.org/10.15517/RBT. V54I3.14078

Ansari, K., Lyla, P. \& Ajmal-Khan, S. (2012). Faunal composition of metazoan meiofauna from the southeast continental shelf of India. Indian J. Mar. Sci., 41(5), 457-467.

Armenteros, M., Ruiz-Abierno, A., Fernández-Garcés, R., Pérez-García, J., Díaz-Asencio, L., Vincx, M. \& Decraemer, W. (2009). Biodiversity 
Spatial and temporal variations of the subtidal meiobenthic community of the central coast of Venezuela

patterns of free-living marine nematodes in a tropical bay: Cienfuegos, $\mathrm{Ca}-$ ribbean Sea. Estuar. Coast. Shelf. Sci., 85, 179-189. https://doi.org/10.1016/j. ecss.2009.08.002

Avilés-Ramírez, G., González-León, J., Poot-Esparza, A., Medina-García, M. \& Rojas-González, R. (2016). Influencia de arrecifes artificiales reef ball de la ensenada de Xpicob, sobre la estructura de la meiofauna y sedimentos recientes. Agroproductividad, 9(9), 44-49.

Baia, E. \& Venekey, V. (2019). Distribution patterns of meiofauna on a tropical macrotidal sandy beach, with special focus on nematodes (Caixa d'Água, Amazon Coast, Brazil). Braz. J. Oceanogr., 67, e19230. https://doi.org/10.1590/ S1679-87592019023006701

Bezerra, T., Decraemer, W., Eisendle-Flöckner, U., Hodda, M., Holovachov, O., Leduc, D., ... \& Vanreusel, A. (2020). Nemys: World Database of Nematodes. http://nemys.ugent.be

Castellanos, P., Varela, R. \& Müller-Karger, F. (2002). Descripción de las áreas de surgencia al sur del mar Caribe examinadas con el sensor infrarrojo AVHRR. Mem. Soc. Cs. Nat. La Salle, 154, 55-76.

Chindah, A. \& Braide, S. (2001). Meiofauna occurrence and distribution in different substrate types of bonny brackish wetland of the Niger Delta. J. Appl. Sci. Environ. Manag., 5, 33-41. https://doi. org/10.4314/jasem.v5i1.54937

Clarke, K., Gorley, R., Somerfield, P. \& Warwick, R. (2014). Change in marine communities: An approach to statistical analysis and interpretation. United Kingdom: PRIMER-E, Plymouth Marine Laboratory.

Conway, D. (2012a). Marine zooplankton of southern Britain. Part 1: Radiolaria, Heliozoa, Foraminifera, Ciliophora, Cnidaria, Ctenophora, Platyhelminthes,
Nemertea, Rotifera and Mollusca. In A. John (Ed.), Occasional Publications (pp. 1-138). England: Marine Biological Association of the United Kingdom.

Conway, D. (2012b). Marine zooplankton of southern Britain. Part 2: Arachnida, Pycnogonida, Cladocera, Facetotecta, Cirripedia and Copepoda. In A. John (Ed.), Occasional Publications (pp. 1-163). England: Marine Biological Association of the United Kingdom.

Coull, B. (1970). Shallow water meiobenthos off the Bermuda platform. Oecologia, 4, 325-357. https://doi.org/10.1007/ BF00393393

Coull, B. (1999). Role of meiofauna in estuarine soft-bottom habitats. Aust. J. Ecol., 24, 327-343. https://doi. org/10.1046/j.1442-9993.1999.00979.x

Coull, B. \& Bell, S. (1979). Perspectives of marine meiofaunal ecology. In R. Livingston (Ed.). Ecological Processes in Coastal and Marine Systems (pp. 189-216). USA: Plenum Publishing Corporation. https://doi. org/10.1007/978-1-4615-9146-7_10

Day, J. (1967). A monograph on the polychaeta of Southern Africa. England.: British Museum Natural History. https://doi. org/10.5962/bhl.title.8596

Decho, A., Hummon, W. \& Fleeger, J. (1985). Meiofauna-sediment interactions around subtropical seagrass sediments using factor analysis. $J$. Mar. Res., 43, 237-255. https://doi. org/10.1357/002224085788437389

Díaz-Asencio, L., Armenteros, M., Díaz-Asencio, M., Fernández-Garcés, R., Gómez-Batista, M. \& Alonso-Hernández, C. (2009). Spatial and temporal variations of meiofaunal communities in Cienfuegos Bay, Cuba. Rev. Biol. Mar. Oceanogr., 44(1), 13-22. http://dx.doi.org/10.4067/ S0718-19572009000100002 
Dupuy, C., Thanh, H., Mizrahi, D., Jourde, J., Bréret, M., Arogué, H., ... \& Bocher, P. (2015). Structure and functional characteristics of the meiofauna community in highly unstable intertidal mudbanks in Suriname and French Guiana (North Atlantic coast of South America). Cont. Shelf Res., 110, 39-47. https://doi.org/10.1016/j.csr.2015.09.019

Dye, A. \& Lasiak, T. (1986). Microbenthos, meiobenthos and fiddler crabs: trophic interactions in a tropical mangrove sediment. Mar. Ecol. Prog. Ser., 32, 259-264. https://doi.org/10.3354/ meps032259

Edwards, C. (2009). Meiobenthos of the discovery Bay Lagoon, Jamaica, with an emphasis on nematodes. (Unpublished doctoral thesis). University of London, England.

Fiers, F. (1984). Harpacticoid copepods from the West Indian Islands: Canuellidae and Longipediidae (Copepoda, Harpacticoida). Bijdragen tot de Dierkunde, 54(2), 197-210. https://doi. org/10.1163/26660644-05402006

Fiers, F. (1986a). Harpacticoid copepods from the West Indian Islands: Laophontidae (Copepoda, Harpacticoda). Amsterdam Expedition to the West Indian Islands, Report 48. Bijd. Dierkunde, 56, 132-164. https://doi. org/10.1163/26660644-05601009

Fiers, F. (1986b). Harpacticoid copepods from the West Indian Islands: Darcythompsoniidae (Copepoda, Harpacticoida). Amsterdam Expedition to the West Indian Islands, Report 51. Bijd. Dierkunde, 56, 282-290. https://doi. org/10.1163/26660644-05602008

Fiers, F. (1995). New Tetragonicipitidae (Copepoda, Harpacticoida) from the Yucatecan continental shelf (Mexico), including a revision of the genus
Diagoniceps Willey. Bull. Inst. R. Sci. Nat. Belg., 65, 151-236.

Giere, O. (2009). Meiobenthology - the microscopic motile fauna of aquatic sediments. Germany: Springer-Verlag.

Gourbault, N., Warwick, R. \& Helléouet, M. (1998). Spatial and temporal variability in the composition and structure of meiobenthic assemblages (especially nematodes) in tropical beaches (Guadeloupe, FWI). Cah. Biol. Mar., 39, 29-39. https://doi.org/10.21411/ CBM.A.452BA5CD

Guzmán, H., Obando, V. \& Cortés, J. (1987). Meiofauna associated with a Pacific coral reef in Costa Rica. Coral Reefs, 6, 107-112. https://doi.org/10.1007/ BF00301379

Hammer, O., Harper, D. \& Ryan, P. (2001). PAST: Paleontological statistics software package for education and data analysis. Palaeontologia Electronica, 4(1), 1-9. http://palaeo-electronica. org/2001_1/past/issue1_01.htm

Hansen, J., Alongi, D., Moriarty, D. \& Pollard, P. (1987). The dynamics of benthic microbial communities at Davies Reef, central Great Barrier Reef. Coral Reefs, 6, 63-70. https://doi.org/10.1007/ BF00301375

Herrera, A. \& Bone, D. (2011). Influence of riverine outputs on sandy beaches of Higuerote, central coast of Venezuela. Lat. Am. J. Aquat. Res., 39(1), 56-70. https://doi.org/10.4067/ S0718-560X2011000100006

Johnson, W. \& Allen, D. (2012). Zooplankton of the Atlantic and Gulf Coasts. A guide to their identification and ecology. USA: The Johns Hopkins University Press.

Kitahashi, T., Kayama, H., Tsuchiya, M., Yamamoto, H. \& Yamamoto, H. (2018). A new method for acquiring images of meiobenthic images 
Spatial and temporal variations of the subtidal meiobenthic community of the central coast of Venezuela

using the FlowCAM. MethodsX, 5, 1330-1335. https://doi.org/10.1016/j. mex.2018.10.012

Kumary, A. (2016). Temporal variations in the distribution of interstitial meiofauna along the southwest coast of India. J. Climatol. Weather Forecast., 4(3), 178-141. https://doi. org/10.4172/2332-2594.1000178

Liñero, I., Ojeda, S. \& Amaro, M. (2013). Variación espacio-temporal de la meiofauna submareal en una playa arenosa nororiental de Venezuela. Rev. Biol. Trop., 61(1), 59-73. https://doi. org/10.15517/RBT.V61I1.10884

Martín, A., Malavé, L., Sánchez, D., Aparicio, R., Arocha, F., Bone, D., ... \& Zoppi, E. (2007). Línea base ambiental Plataforma Deltana. Venezuela: Petróleos de Venezuela, S. A., Universidad Simón Bolívar.

Mokievskii, V., Udalov,A. \&Azovskii,A. (2007). Quantitative distribution of meiobenthos in deep-water zones of the world ocean. Oceanology, 47(6), 797-813. https://doi. org/10.1134/S0001437007060057

Moncreiff, C. \& Sullivan, M. (2001). Trophic importance of epiphytic algae in subtropical seagrass beds: Evidence from multiple stable isotope analyses. Mar. Ecol. Prog. Ser., 215, 93-106. https:// doi.org/10.3354/meps215093

Netto, S., Attrill, M. \& Warwick, R. (2003). The relationship between benthic fauna, carbonate sediments and reef morphology in reef-flat tidal pools of Rocas Atoll (north-east Brazil). J. Mari. Biol. Assoc. UK, 83, 425-432. https://doi. org/10.1017/S0025315403007288h

Osorio-Dualiby, D. \& Álvarez-León, R. (2011). Characterization of meiobenthos in areas of coastal influence by two companies located in the industrial zone of Mamonal, Cartagena Bay,
Colombia. Arq. Ciên. Mar., Fortaleza, 44(1), 81-96.

Owre, H. \& Foyo, M. (1967). Copepods of the Florida Current with illustrated keys to genera and species. USA: Institute of Marine Science, University of Miami.

Páez, M., Zúñiga, O., Valdés, J. \& Ortlieb L. (2001). Foraminíferos bentónicos recientes en sedimentos micróxicos de la bahía Mejillones del Sur $\left(23^{\circ} \mathrm{S}\right)$, Chile. Rev. Biol. Mar. Oceanogr., 36, 129-139. http://dx.doi.org/10.4067/ S0718-19572001000200002

Pereira, C., Fernández, A., Hernández, V. \& Troccoli-Ghinaglia, L. (2020). Ocurrencia de floraciones nocivas de microalgas en las costas del estado Miranda, Venezuela. Cienc. Amb. Clima, 3(1), 55-71. https://doi.org/10.22206/ cac.2020.v3i1.pp55-71

Pérez-García, J., Ruiz-Abierno, A. \& Armenteros, M. (2020). A checklist of aquatic nematodes from Cuban Archipelago. Zootaxa, 4731(3), 301-320. https://doi. org/10.11646/zootaxa.4731.3.1

Platt, H. \& Warwick, R. (1983). Free-living marine nematodes. Part 1. British Enoplids. England: The Linnean Society of London, The Estuarine and Brackish-Water Sciences Association.

Platt, H. \& Warwick, R. (1988). Free-living marine nematodes. Part 2. British Chromadorids. Netherlands: The Linnean Society of London, The Estuarine and Brackish-water Sciences Association.

Reyes, J., Godoy, A. \& Casler, C. (1999). Invertebrados bentónicos del bosque de manglar de la ciénaga de Los Olivitos, Venezuela. Bol. Centro Invest. Biol., 33(3), 227-241.

Ruiz-Abierno, A. \& Armenteros, M. (2016). Coral reef habitats strongly influence the diversity of macroand meiobenthos in the Caribbean. Mar. Biodiv., 
47, 101-111. https://doi.org/10.1007/ s12526-016-0553-7

Sabbatini, A., Morigi, C., Nardelli, M. \& Negri, A. (2014). Foraminifera. In S. Goffredo \& Z. Dubinsky (Eds.). The Mediterranean Sea: Its history and present challenges (pp. 237-256). England: Springer Science. https://doi. org/10.1007/978-94-007-6704-1

Schnack-Schiel, S. \& Isla, E. (2005). The role of zooplankton in the pelagic-benthic coupling of the Southern Ocean. Sci. Mar., 69(2), 39-55. https://doi. org/10.3989/scimar.2005.69s 239

Schwarz, T. (2014). AmbiWeb GmbH. Clima Higuerote. https://es.climate-data.org/america-del-sur/venezuela/ estado-miranda/higuerote-27656/

Solé, M. \& Vera, B. (1997). Caracterización de las macroalgas marinas bénticas en la región Chirimena-Punta Caimán, Edo. Miranda, Venezuela. Carib. J. Sci., 33(3-4), 180-190.

Soltwedel, T. (2000). Metazoan meiobenthos along continental margins: a review. Progr. Oceanogr., 46, 59-84. https://doi. org/10.1016/S0079-6611(00)00030-6

Suárez-Morales, E. \& Gasca, R. (1997). Copépodos (Crustacea) de las aguas superficiales del Mar Caribe Mexicano (mayo, 1991). Rev. Biol. Trop., 45, 1523-1529.

Todd, C. \& Laverack, M. (1991). Coastal marine zooplankton: a practical manual for students. USA: Cambridge University Press.

Trégouboff, G. \& Rose, M. (1967a). Manuel de planctonologie Méditerranéenne. Tome I, texto. France: Centre National de la Recherche Scientifique.

Trégouboff, G. \& Rose, M. (1967b). Manuel de planctonologie Méditerranéenne. Tome II, planches. France: Centre National de la Recherche Scientifique.
Vásquez-Suárez, A., González, M., Díaz, O. \& Liñero, I. (2010). Variación temporal de la meiofauna en sedimentos del sistema lagunar "Laguna de Raya", estado Nueva Esparta, Venezuela. Interciencia, 35(2), 144-150.

Venekey, V., Parreira, P. \& Gomes, V. (2014). The influence of tidal and rainfall cycles on intertidal nematodes: a case study in a tropical sandy beach. Braz. J. Oceanogr., 62(4), 247-256. https://doi.org/10.1590/ s1679-87592014061706204

Wang, X., Liu, X. \& Xu, J. (2019). Distribution patterns of meiofauna assemblages and their relationship with environmental factors of deep sea adjacent to the Yap Trench, Western Pacific Ocean. Front. Mar. Sci., 6(735), 1-12. http:// doi.org/10.3389/fmars.2019.00735

Warwick, R., Platt, H. \& Somerfield, P. (1998). Free-living marine nematodes. Part 3. British Monhysterids. England: The Linnean Society of London, The Estuarine and Brackish-Water Sciences Association, Cambridge University.

Warwick, R. (2018). The contrasting histories of marine and freshwater meiobenthic research-result of differing life histories and adaptive strategies? J. Exp. Mar. Biol. Ecol., 502, 4-11. http://dx. doi.org/10.1016/j.jembe.2017.05.008

Wells, J. B. J. (1978). Keys to aid in the identification of marine harpacticoid copepods. Amendment Bull. No. 1. Zoology Publi. Victoria Univ. Wellington., 70, 1-11.

Wells, J. B. J. (1979). Keys to aid in the identification of marine harpacticoid copepods. Amendment Bull. No. 1. Zoology Publi. Victoria Univ. Wellington., 72, 1-8.

Willey, A. (1930). Harpacticoid Copepoda from Bermuda. Part. I. Ann. Mag. Nat. Hist., 6, 81-114. https://doi. org/10.1080/00222933008673192

Willey, A. (1932). Copepod phenology. Observations based on new material from 
Spatial and temporal variations of the subtidal meiobenthic community of the central coast of Venezuela

Canada and Bermuda. Atti del Congresso Internazionale Zoologica, 1930. Archo. Zool. Ital., 16(2), 601-617.

Willey, A. (1935). Harpacticoid Copepoda from Bermuda. Part. II. Ann. Mag. Nat. Hist., 15, 50-100. https://doi. org/10.1080/00222933508654944

Woods, D. \& Tietjen, J. (1985). Horizontal and vertical distribution of meiofauna in the Venezuela Basin. Mar. Geol., 68, 233-241. https://doi. org/10.1016/0025-3227(85)90014-3

Wołowicz, M., Sokołowski, A., Urban-Malinga, B. \& Szymelfenig, M. (2011). Meiofauna as consumers in coastal food webs. In E. Wolanski \& D. McLusky (Eds). Treatise on estuarine and coastal science (pp. 173-202). Poland: Elsevier. https://doi.org/10.1016/ B978-0-12-374711-2.00611-2
WoRMS Editorial Board. (2020). World Register of Marine Species. http://www. marinespecies.org

Zaleha, K., Nasiratul, M., Siang, H. \& Kamaruzzaman, B. (2016). Trend of meiobenthos density and composition in Karah Island, South China Sea. Sains Malaysiana, 45(7), 1019-1024. 
